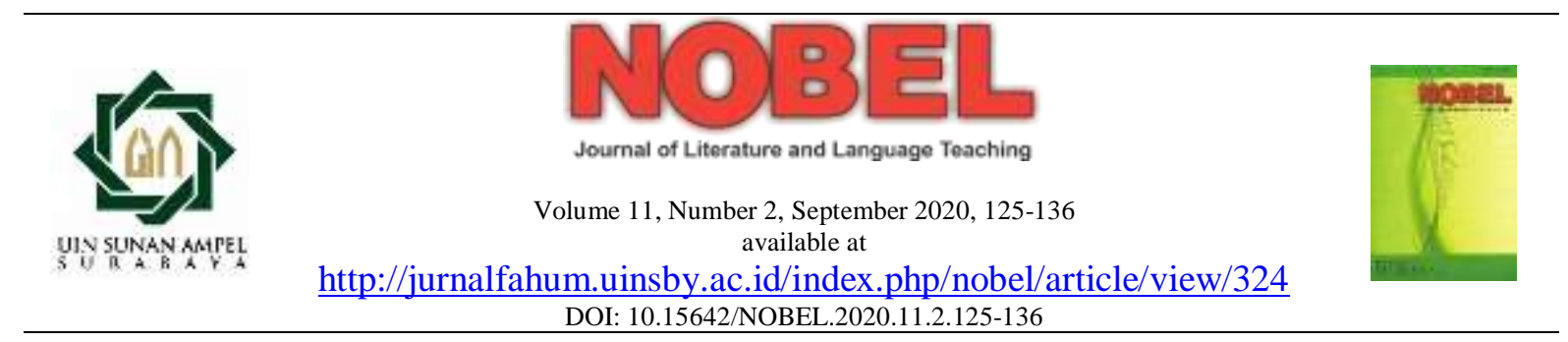

\title{
WILLIAM GOLDING'S LORD OF THE FLIES: A RECONSIDERATION
}

\section{Mariwan Hasan $^{1 \bowtie}$, Diman Sharif ${ }^{2}$}

Sulaimani University, Sulaimani, Iraq

\begin{tabular}{l}
\hline Article Info \\
\hline Article History: \\
Received July 2020 \\
Accepted August 2020 \\
Published September 2020 \\
\hline Keywords: \\
allegory, fable, \\
symbolism, education, \\
civilization \\
\hline
\end{tabular}

\section{Abstract}

This paper reconsiders Lord of the Flies, written by William Golding, on its use of allegory. The novel was written in connection with incidents of the $20^{\text {th }}$ century and the novelist's own experience. In the beginning, the paper introduces the novelist's opinion on human beings through allegory and fable that encouraged the reader and listener to look for hidden meanings. Then it deals with the cultural approaches famous at that time for utilizing symbolism within the novel. Finally, it tackles educational value through his experiences. The findings show that Lord of the Flies is both a historical and political allegory for life after World War II. It also symbolizes the nature of humankind, which then serves as a teaching device for human civilization both in the classroom and in the real-life. 


\section{INTRODUCTION}

Golding's Lord of the Flies has become well-known in the modern age. "It was written as a response to World War II to trace to the defects of society back to the defects of human nature. William Golding is considered one of the most distinguished British novelists of the twentieth century" (Reiff, 2010). 1954 is the publication date of the novel. "Lord of the Flies is one of the most important texts of the twentieth century, for both literary and extra-literary reasons" (Reiff, 2010).

The novelist's experience in World War II had encouraged him to seek the true factors behind this damaging war. "Lord of the Flies was written shortly after World War II when the world was in the conflict between the liberal democracy and totalitarian communism" (Kelly, 2007). Golding was traumatized by the events of the war, which he fought in, and the terrors it brought with itself. This experience served a source of inspiration for the author to write how devilish a human can be and that every single human being can involve in such monstrosities. He also aimed to demonstrate the fact that even in a civilized society like that of England, evil acts can emerge as well as anywhere else. The novel was intended to be a tragic lesson that English have had to learn over period of one hundred years.

The writing of this novel was a reaction to the novel by R.M Ballantyne, written in 1857. The novel is called The Coral Island that tells about a bunch of young men left the ground on an island. These boys bring together the environment of the island as they face its human flesh-eating dwellers. One of us has looked at this novel as an allegory through which a lot can be inferred, and he believes it is this obscurity and vagueness that made this novel quite popular and a "modern classic" novel (Barzinji, 2012; Hasan, 2015; 2016).

Golding's aesthetic view of life and the aestheticism in his writing have contributed to keeping his novel permanently new: the content of his writing fits the present and past. Under a rather complex title, Golding wants to lay a foundation for reform since life is bound to get more complicated day by day and century by century. Eventually, everything will require symbols. In the end, I would like to say that the title of the novel completely fits its content. The pig and fly, which signified evil, oppression, and problem, were complete with both layers of the land and air, signifying destruction and annihilation.

Golding was a realist who expressed the true reality of the incidents of his time as a modern writer through his wide imagination. In choosing the title of his novel, he has worked creatively using symbols; his writing would stand out among other authors who had the same writing style. Under the title of the novel, the author says that there exist not only "flies" but also their "lord." 
From the time of its publication, Lord of the Flies became considerably well-known. In 1960, the novel served as the reading material for many schools and university curriculums. This novel explores the abysmal depths of the human mind. Golding shows how bizarrely human beings conducted themselves in the size-varied situation- when human beings overlook their worldly existence. They are prone to engaging in wars to the point of death, due to the nature of war in dwindling societies. This novel is an actual reflection of life in the final half of the $20^{\text {th }}$ century when society looks like it had achieved technological ripeness as the morality of man yet to be matured. The primary years of the $20^{\text {th }}$ century marked the most important ones in the history of England. Numerous changes occurred. These changes manifested themselves in the prompt progress of education, technology, and science. Human beings' state of affairs enhanced considerably. Literature may be described as the echo of society to illustrate a particular occurrence or to discover a resolution for a definite quandary.

The researchers believe that every work of literature is marked by the author's use of language and style to convey their message. Each author, hence, has his/ her method of doing this, and that is why he employs the figures of speech, for instance, fable, metaphor, symbolism, and irony. Among such tools of message delivery, allegory stands out owing to its high significance. Abrams and Harpham (2012) defines allegory as "a narrative, whether in prose or verse, in which agents and actions, and sometimes the setting, are contrived by the another to make coherent sense on the lethal or primary level of signification and at the same time to communicate a second, correlated order of signification."

Chaucer's The Canterbury Tales was an old literary work that utilized symbolism "allegory." The researchers believe that utilizing symbolism as an artistic literary style, a non-concrete notion takes up the form of a conventional tangible object and becomes more actual prominent. The importance of symbolism is quite apparent in the literature. The author employs symbolism to maintain the overview of the story; it is also beneficial for the reader because it helps him/ her to comprehend the text with ease. Through it, the author uses various sorts of symbols, characters, objects, living things, colors, and locations to deliver the message of the central theme.

Lord of the Flies is considered as a model allegorical writing that represents humanity's wicked disposition. The researchers think that allegory in the novel has been realized through the character depictions, storytelling method, and happenings. Allegory is both an imaginative and a developmental progression expressing symbols and themes. Golding's dealing with the human condition is limited by the form of a fable, which favors the importance of action. The human condition here refers to the disparity between the morality 
and intellectuality between the people and human beings. There have been many writing attempts targeting Golding's novel, precisely its meaning.

Kennedy (1991) has labeled this novel as a "fable" or "allegory." Despite this, there is a contrast between the two terms. Allegory is explained as an account, whether in prose or verse, through which concrete elements like "characters, settings, actions" are utilized as symbols or allegory to render moral, religious, and political ideas. Meanwhile, "fable, more or less similar, is brief and has a humorous narrative that teaches moral lessons." Thus, it could be argued that Lord of the Flies leans more towards allegory since it holds numerous symbols and occurrences filled with symbols.

\section{DISCUSSION OF MAIN THEMES}

\section{Lord of the Flies as an Allegory}

Historical characters and events are represented by the discourse and actions in historical and political allegories. The person is the focal point of morality, immorality and disposition, styles of life, and different characters and places in the second type of allegory. Lord of the Flies is a striking combination of the afore-mentioned allegories. Mainly, non-allegorical works in nature are likely to present allegorical descriptions provided that representations of the abstract things are not following the things engaged in transitory allegorical actions like Milton's L'Allegro and II Penseroso (1646).

Allegory is a narrative technique that perhaps has been used in any literary genre, and Everyman, as a morality play, is the earliest example of it. Allegory has been less used in the twentieth century. However, it has gained the attention of some contemporary writers and theorists. Since its first publication, Lord of the Flies has been recognized as an allegory of ideas or themes represented by the characters. However, because "Golding is a simply complicated writer, the characters are not straight forward representations of only one idea. They can represent various categories of allegories, political, sociological, religious, and psychological” (Reiff, 2010).

An allegory is a form of imaginative literature which encourage the readers are to seek hidden meanings beneath the literal surface. Allegory involves either a creative or informational process which shows symbols and themes. There are historical and political allegories in which character and actions tend historical parsing and events. In other type of allegory, which is the allegory of ideas, the central device is the personification of abstract entities such as virtues, vices, state of mind, modes of life, and types of character and places.

Lord of the Flies is a beautiful fusion of these two types of allegories, with a figurative 
level of meaning and moral teaching lesson. The novel is allegorical with the historical and cultural contexts, which is the conflict between dictatorships and democracy in World War II. Meanwhile, the water is used to teach mood, ethical, or religious lessons with satirical political purposes to convey a message. The resonances of "the flies are not allegorically simple, but ideographically suggestive. Everything is twofold. "Very perspective provokes a competing alternative" (Reilly, 1988). Golding adopts a realistic approach that presents both positive and negative, pessimistic, and optimistic thinking. His experience in World War II had encouraged him to seek the real reasons behind these destructive wars.

The novel also takes a form as religious allegory. It merely focuses on human beings' "morality, ethics, and values," which finally established a pleasant "social life." What Golding insists is the ability of the individual to rule himself, not the rule of law. Due to these factors, the novel is completely a religious allegory. Lord of the Flies is also an example of dystopian fiction because it presents the characters as living in a nightmarish, oppressive society due to their inherently flawed natures. In direct contrast to utopian fiction, which persists that human beings are perfectible and society force of suffering is possible, dystopian fiction asserts that societal injustice is inevitable. The genre becomes popular during the $20^{\text {th }}$ century when works like George Orwell's Animal Farm employ fear, suspense, and often violence to warn readers about the dangers in democratic processes.

Lord of the Flies, which was somewhat intellectually or philosophically contrived, has become the major critical assumption about the rest of Golding's work. The many references to dirt and excrement underline the violence of human nature. "The two concepts merge in Golding's agitation, covertly in Lord of the Flies, which is full of that revulsion psychologists try to explain in terms of the proximity and ambiguity of the apertures utilized for birth and excreta" (Oldsey \& Weintraub, 1998, p. 30).

Golding uses light-dark contrasts traditionally; images associated with the pig's head on a stick is allegorical of dialogue. Lord of the Files "becomes a blatant allegory in which each spokesman caricatures the position he defends" (Baker, 2000, p. 10). The novel, thus, becomes a unique example of a political and religious allegory as well as an allegory of ideas. "Lord of the Flies is an allegory on human society today; the novel's primary implication being that what we have come to call civilization is a best on more than skin deep" (Baker, 2000, p. 12).

\section{William Golding and the Use of Fable in Lord of the Flies}

Lord of the Flies carries the qualities of realistic fiction, but at the same time, they have a 
system of symbolism that leads to an allegorical meaning in modern fabulation. It tends to be away from the representation of reality, still, it returns toward actual human life by way of ethically controlled fantasy. Many fabulists are allegorists, but the modern fabulists allegorize in peculiarly modern ways. Golding "is one of these modern fabulators, and his writings have a direct purpose of analyzing human life and its dilemmas" (Ichiko, 2000).

Lord of the Flies has been called a "fable." Golding himself has used the term 'fable' to describe his novel, suggesting that "fabulist is a moralist." He cannot make a story without a human lesson tucked away in it (Ichiko, 2000). In saying this, Golding points to the simplicity of the story was told. Golding tries to present his truth as accurately as possible by giving a successful reality to the boys and their environment. The edge of the lagoon becomes a streak of phosphor scene, which advanced minutely as the great waves of the tide flowed. The clear water with an inevitable syllable and moved on (Lord of the Flies 8).

\section{Golding's Personal Experience Reflected in Lord of the Flies}

Several great incidents took place in the twentieth century, but the two devastative ones were the two World Wars that shifted the manner of people, including William Golding. His life was influenced by the disasters and shocks of war, which left an unforgettable stamp on his literary career. The horrors of World War II helped him to perceive some kind of innate human evil like that explored in Lord of the Flies. Golding himself stated that Lord of the Flies "takes the supposed innocent experience of the island-like life to test it against the experience of Nazism and Second World War." (quoted in Olsen, 2000, p. 10)

During the war in the sea, Golding realized the brutality of people to one another and saw different types of "inhumanity and persecution." As Keating (1979) puts it, "evil is inherent in man; a terrifying force which he must recognize and control" (191). The researchers believe that Golding's most novels reflect the inference of this shift in thinking in his war experience changed his view about humankind's essential nature. When World War II began in 1939, he was a young man and, during the war, he served in the Royal Navy, which is the key factor of why Golding is so respected in his first novel.

Lord of the Flies is an allegory that focuses on the loss of innocence and revealing the true nature of humans and society with a very special history. Golding believes that human nature is deeply corrupted and the evil of man is multiplied and transferred. Golding tries to show that the defects of the society are a consequence of the defects of the individual, and society can become an augmented version of it in some circumstances. Golding has successfully conveyed the messages of Lord of the Flies by portraying the hateful nature of 
mankind through the use of symbolism throughout the novel. Symbolism, which is of both characters and other significant objects, is used to stress the message of the novel. "Golding's story offers such a good model of novel structure, character development, and symbolism that it is almost necessary for English classroom" (Chaima, 2015, p. 195).

There were some novelists such as Alan Sillitoe, Kingsley Amis, and John Brain, who shared annoyance with tradition, authority, and the ruling class. Their works reflected their anger and dissatisfaction. Many novels were for the working-class of depressed cities in the industrial north. Like the author themselves, they are impatient and critical of conservative morality and behavior. They seem angry and violent. They meant that dissent, honesty was introduced into literature by a group of writers known as the "Angry Young Men." When the Angry Young Men were starting a literary movement emphasized unadorned realism and a revolt against intellectual culture in the middle of the 1950s, William Golding began writing novels of a very different kind, unlike those of the group.

\section{On Symbolic Significance of Characters in Lord of the Flies}

The characters in Lord of the Flies have the prominent features that make them like people at school, work, and society and become examples of special features of human nature persuasively. In each novel, an object may represent something other than the actual meaning. The researchers believe that in Lord of the Flies, William Golding used several objects representing several elements like characterization, setting, and action. These elements imply certain contradictories.

"Golding works out his themes employing symbolism" (Michot, 1990, p. 82). The researchers believe that Lord of the Flies carries symbols that show the hidden or deeper meaning. Symbolism is one of the most puzzling aspects of this novel. Golding uses different characters to raise the conflict in his novel. Each of the main characters can be seen as an allegorical representation of a certain aspect of human nature. All the boys undergo certain changes in their new environment, and being in isolation has affected their attitudes and life differently.

Lord of the Flies takes place on an island during World War II. The setting is significant since the isolation forms a sort of civilization. The island in the novel is similar to our society in many ways, as a kind of metafiction. Certain objects link the island and our society.

Golding portrays the conch as a symbol of power, order, and authority. The researchers think that an important theme in this novel is social power relations. One may think that these power relations are everywhere on the island and are shown at different levels and situations 
throughout the novel. These power relations are illustrated by symbols in the novel, which centers on two different power systems, a democratic and dictatorial one. Ralph becomes democratic leader while Jack is the dictatorial.

The island is shaped because the ocean by which is surrounded the island stands for the boundary between civilization. Golding thinks widely for all these things of human beings indeed, for life, place, food, and the objects needed, for instance, knife, stick, light, conch for awareness. The ocean makes the boys sail deeply inside themselves to discover what is there inside the island, and its jungle takes the role of a microscope, which will enable one to see things he can never see by his abstract eyes.

Another powerful symbol is the beast, which embodies the power of the boy's fear. All the boys can be frightened. They are scared of something that does not even exist. Jack uses the fear of the boys as a chief source of power. These situations clearly show that Jack is willing to do everything to remain the chief of the island. The researchers believe that the fear and frustration darken the boys' hearts, without any law and order were found in all places on the island.

Ralph is the representative of civilization. The conch shell, with which he claws to call the boys to meetings and puts into the hands of any boy who wishes to speak, while others must keep silent and listen to him, represents an authority balancing a democratic society with equal rights freedom. He lives by rules, acts peacefully, and follows moral commands and values the good of the group, who dramatically reveals the condition of civilization and democracy in Golding's time.

Piggy is the embodiment of intellect and rationalism, which is like a sacrificial pig impaled on the sharpen stick since anarchy and animalism is in dominion. The researchers assert that his eye-glasses are both a tool for the boys setting the fire and a symbol of reason and rescue, "We don't want another night without fire" (Lord of the Flies 162). It is his belief in a spiritual reality that diminishes his fear of darkness, and he enters the dark forest without any fear of a strange "beast."

Simon has found the truth that the imaging beast is horrible. There are so many symbolic used in this novel the researchers try to mention in different sections occasionally. The three main characters Ralph, Piggy, and Simon, along with an uncounted of other boys, enact a savage human triaged of hunting and killing when they have the chance to create a perfect life for themselves. 


\section{The Value of Education in Lord of the Flies}

The Symbolism in Lord of the Flies effectively teaches students about literary devices and methods, and civilization. Through four main characters in the novel, Golding uses the key personalities of Ralph, Jack, Piggy, and Simon to portray different elements of society.

Golding's story of a group of British School boys to preach good reason and virtue lies in his authorial talent. The researchers think that Golding's experience in teaching helps his textual intelligence by focusing on how Lord of the Flies achieves the effect. The allegorical nature of the novel is so carefully constructed and presented that readers can endlessly go beyond the superficial action and dialogue. Olsen (2000) argues that "at every reading, I found something new. Sometimes, the questions and ideas arose so fast that some of them slipped away before I could get them down on paper. The text employs such simple, ancient symbols ... that thousands of years of cultural history can be read into them. A reader could spend an entire year tracking down illusions, interpretations, and sources" (p. 12).

More commonly, in high school classrooms, teachers educate students about literary devices demonstrated in classic writings. Additionally, students are taught how these devices serve to enhance the meaning of a particular text or how they uniquely characterize the author. Such basic devices as symbolism, foreshadowing irony, and personification are illustrated in most required readings of the High School students. The majority of scholars agree that the novel possesses a unique literary value. Golding demonstrates exceptional employment of symbolism, plot, and character devices that make him win the Nobel Prize for Literature (Monk \& Pistolis, 1996).

Golding's first novel can elicit this kind of insightful response following class readings. It is a valuable novel to us, not because it tells us about the darkness of man's heart but because it shows a work of art that enables us to enter into the world it creates and live at the level of a deeply perceptive and intelligent man.

The student's insight is an agreeable conclusion of many scholars. As Baker (2000) suggests, Golding mirrors the history of the world. Lord of the Flies was published ten years after World War II. For centuries, countless nations and peoples have been warring, and imposing values and restrictions upon one another. "The beast-man comes to the shore, for he bears in his nature the bitter promise that things wall remains as they are - and as they have been since his first appearance ages and ages ago" (p. 17). Bloom (2008) states that Lord of the Flies was one of the great story-seller of our time, always exploring the moral message which Golding delivers. The study of historical research has quite often taken an interest in moral education because the novel or the fable of the novel deals with the theme of moral 
values in fables. Golding intends to deliver a message which is "moral" that society holds all together, "and with civilization and rules, man's ideals, values, and basic ideas of what is right and wrong are set, to stand strongly against the emergence of humanity's evil nature."

\section{Critical Analysis of Lord of the Flies}

Lord of the Flies is full of adventures and allusions. Thus, it needs limitless interpretation and criticism. It deals with deep subjects and is varied critical. Most of them think that the novel contributes to value and will prove its widespread and reputation. The novel is very thorough in terms of meaning, structure, and style. Golding's novel is seen as a version of the human experience, especially during World War II, and a study of human value and human nature. It is also asserted that the most human evils are attributed to repressive and overly demanding ways of life, caused by adherence to the false conventions and values of civilization. Another important part of Golding's technique is the character presentation that Golding creates each represents one side of human nature. Jack is ambitious for gaining power, which is not safe. "life on the island...only imitates the larger tragedy in which the adults of the outside world attempt to govern themselves reasonably, and ends in the same game of hunt and kill” (Baker, 2000, p. 23).

The researchers argue that Lord of the Flies is Golding's theory of man's inherited nature. The savagery and primitiveness of human nature will reveal itself when the restraints of civilization are missing, such as laws and rules necessary to keep the darker side of human nature in line. Golding confirms his theory by using allegory like characterization, setting, and action showing all these things of understanding the nature of their humanity. The child is the purest being of humanity- "childhood represents humanity's original, imaginative enthusiasm for the world" (Baker, 2000). Golding skillfully used foreshadowing in Lord of the Flies. The arrival of the officer reflects the writer's gloomy mood, and many expressed about the future of humankind and reflected the mood in post-war European society. It is claimed that Golding destroyed equality between races. However, the negative view of the novel is that the story seems psychologically unsuitable for children's age. It is well written, unusual, and frightening, where the boys are occupied by a mysterious phenomenon that brings them fear. Thus, this novel is advised for the 14-16 age group (Hawlin, 2008).

Tiger (2003) maintains that the novel "consists of two movements told from two points of view. In the first, the events are seen from the point of view of the childish protagonist.... in the second movement, the code which concludes the text, the reader encounters events from a new point of view, that of an adult officer, who is completely unaware and largely 
indifferent to the suffering" (p. 36). The researchers believe that using Golding's experience as a teacher with young children and the war experience he gained during World War II enables him to understand the structure of human nature and the degradation of human society. Roy (2003) sees that the novel refers to Golding's gender bias; to show male's power reveals his image of superiority, which is embodied only in males. It seems that Golding wants to show a strong image of the boys and men. The researchers consider that the absence of the girls in Golding's novel reduces its dangers because the behavior of the hunters was suitable for the remainder of the boys, especially with Jack. He was red, ruddy, and prone to blush when angry and frustrated, he calls (Thyponic) the element of human nature. Golding also used this element as a symbol of human nature. Lord of the Flies dealt with from realism to political allegory, documentary to mythic experimentalism, with that dilemma of continuity. Golding wants to explain that, but it needs more to change the inner evil by goodness and strong belief; moreover, it needs to raise the statue of science rather than authority and wealth.

\section{CONCLUSION}

It is concluded that Lord of the Flies is an allegory of the world Golding experienced, a version of our world. It alludes to many subjects of our society, and it treats many problems. Each allegory reflects a fact, and its motif is an approach to religion, and its major character stands for a specific idea.

Lord of the Flies is very rich and complex because it studies human nature and treats many themes. This complex and variety make it specific and remarkable among many relevant works. Golding's narration in meaning with complete work, which deals with a very deep subject and difficult, needs many points of view to be seen by many eyes in many angles.

The novel is full of ideas that amaze and teach us in many visions. Besides, Lord of the Flies is an example of a political and religious literary work reflecting human society. The symbolism he used is not merely a decorative technique but has a close link with allegory and fable and that both contain many elements and symbols.

\section{REFERENCES}

Abrams, M.H. \& Harpham, G.G. (2012). A glossary of literary terms, (10 ${ }^{\text {th }}$ Ed.). Boston, USA: Wadsworth.

Baker, R.J. (2000) "Golding and Huxley: the fable of demonic possession." Twentieth 
Century Literature, 46(3), 311-327. DOI: 10.2307/441940

Barzinji, M.N.H. (2012). The image of modern man in T.S Eliot's poetry. Bloomington: Author House.

Bloom, H. (Ed.). (2008). William Golding's Lord of the Flies. New York: Bloom Literary Criticism.

Chaima, S. (2015). Symbolism in William Golding's novel Lord of the Flies (1954). Doctoral dissertation (University of Mohamed Kheider Biskra).

Monks, M.M., \& Pistolis, D.R. (1996). Hit list: Frequently challenged books for young adults. Chicago: American Library Association.

Golding, W. (1986). Lord of the flies: London, Faber.

Hasan, M. (2016) “The rise of modernism: a new history of Western modernism." Journal of Kirkuk University Humanity Studies, 11(1), 1-42. Retrieved from: https://www.iasj.net/iasj?func=article\&aId=130559

Hasan, M.N. (2015). The eighteenth century and the rise of the English novel. International Journal of Literature and Arts, 3(2), 18-21. DOI: 10.11648/j.ijla.20150302.12

Hawlin, S. (2008). The savages in the forest: Decolonising William Golding. In H. Bloom (Ed.). William Golding's Lord of the Flies. New York: Bloom Literary Criticism.

Ichiko, T. (2000). Fable, parable, and allegory. Retrieved from: https://www.britannica.com/art/fable-parable-and-allegory/Allegorical-literature-in-theEast

Keating, J. (1979). Interview with William Golding. London: The Macmillan Press.

Kelly, C. (2007). Children's world: Growing up in Russia, 1890-1991. Yale University Press.

Kennedy, W. (1991). The modern allegories of William Golding. USA: University of South Florida.

Michot, P. (1990). "The myth of innocence" in Contemporary literary criticism. Westport, Connecticut: Greenwood Press.

Oldsey, B.S., \& Weintraub, S. (1998). The art of William Golding. Bloomington \& London: Indiana University Press.

Olsen, K. (2000). Understanding lord of the flies: A student casebook to issues, sources, and historical documents. Greenwood Publishing Group.

Reiff, R.H. (2010). William Golding: Lord of the Flies. Tarrytown, NY: Marshall Cavendish Benchmark.

Reilly, P. (1988). The literature of guilt: From 'Gulliver' to Golding. Iowa: University of Iowa Press.

Roy, P.A. (2003). Boys' Club-No Girls Allowed: Absence as presence in William Golding's Lord of the Flies (1954). In J. Fisher \& E.S. Silber (Eds.). Women in literature: reading through the lens of gender. Westport, Connecticut: Greenwood Press.

Tiger, V. (2003). William Golding: The unmoved target. London: Marion Boyars Publishers. 